\title{
THE MAKING OF \\ A MODERN MUSEUM
}

\author{
BY \\ ELEANOR G. HEWITT
}

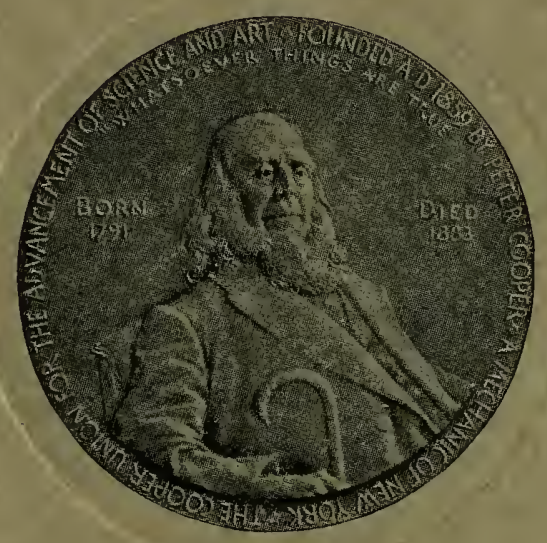

WRITTEN FOR

THE WEDNESDAY AFTERNOON CLUB 1919 


\section{FIRST PRINTING 1919}

SECOND PRINTING 1922

THIRD PRINTING 1926 


\section{THE MAKING OF A MODERN MUSEUM BY \\ ELEANOR G. HEWITT}




\section{FOREWORD}

$T_{N} 1919$ the Wednesday Afternoon Club asked my sister, Eleanor Garnier Hewitt, one of its members, to write a paper on "The Making of a Modern Museum," which they found so interesting that they paid her the unusual compliment of printing it privately for her fellowmembers.

As many others were desirous to read it, the Club kindly consented to the publication of a second edition, which is also exhausted.

The demand for it still continues, so this third edition is now issued as a small tribute to the memory of my sister, who devoted all her talents and the greater part of her time to create and develop the Museum for the Arts of Decoration, which was inaugurated at Cooper Union in 1895 in honor of its Founder, Peter Cooper, in order to complete the work he originally planned.

SARAH COOPER HEWITT. 


\title{
THE MAKING OF A MODERN MUSEUM
}

\author{
By EleAnor G. HewitT.
}

Written for the Wednesday Afternoon Club.

$\mathrm{O}$

NE of the most modern of Museums really originated centuries ago, and such diverse and irrelevant events as religious controversies, fires, escapes, wars, poverty and romance, steam engines and miracles contributed to making it inevitable.

The dissensions of the Royalists and Covenanters have no apparent connection with the matter in hand, but they drove the Cooper family to the colonies so early in the history, that one son was the fourth white man-child born in Dutchess County. His descendants later on conducted a prosperous tile making and pottery business on the present site of Saint Paul's Church, only to lose it when the Hessian troops occupied New York. Having fled again, this time in a farm wagon with such few household goods as they could contrive to load upon it, the family later returned to the city, and to poverty, and once more for a fresh start.

Peter Cooper, who was born in 1781, began his uphill struggle at such an early age, that in spite of his marked ability, he could only spare the time for six weeks' schooling. This, combined with his early trials and subsequent successes, soon gave him the inspiration that it was his duty to place within the reach of others similarly situated, the means of acquiring suitable and practical educations to advance them in their chosen careers.

The Revocation of the Edict of Nantes, the chief cause of the industrial and artistic revival of the world, incidentally sent the ancestors of Mrs. Peter Cooper via Holland to America, and young Isaac Garnier, one of whose descendants married into the Hewitt family, was floated out to sea 
in a barrel from La Rochelle and picked up by a sailing vessel bound for the New World. (There is still a street in La Rochelle called Garnier.)

As religious controversies were responsible for both the Cooper and Garnier families going to America, the steam engine was responsible for coming from England, in 1796, of the talented young mechanic and pattern maker, John Hewitt, who already held his first-class certificate as a cabinet maker.

James Watt, the inventor, confided the setting up of the first stationary steam engine at Soho on the Second River, New Jersey, to this upright young man, since in those days it was harder even to find upright men than now, and skilled mechanics as soon as they were trained were usually bribed away by rival and less able inventors from the firm of Boulton and Watt, who had instructed them.

John Hewitt's romantic marriage with the beautiful descendant of Isaac Garnier, of Haverstraw, kept him from returning to England, so he began a prosperous furniture business in New York, where his work rivalled that of Duncan Phyfe, though it is not known in the North, as his finest pieces were always purchased by the wealthy connoisseurs of Charleston, Mobile, Savannah, and New Orleans.

The total destruction of this business by fire drove him and his family, this time in a Garnier farm wagon sent by their relatives to fetch them, back to the log cabin and a few acres near Haverstraw, Mrs. Hewitt's sole inheritance. Here Abram S. Hewitt was born, and as he grew, it became his ambition to keep his mother from enduring in her old age, as she had endured throughout his youth, hardships more severe than any known in modern times. This ambition added to his eagerness to obtain the education warranted by his brilliant abilities. He succeeded by means of unparallelled effort, and later supplemented and perfected the wonderful work of Peter Cooper, thus fulfilling a decree of 
Destiny, that a second man should come forward to complete the work of the first.

Peter Cooper was really a hundred years in advance of his times. The only Museums of his day were those of Barnum and Woods, and one or two other very small places, which all exhibited natural phenomena and curiosities, but Mr. Cooper, while planning his great building for "education and recreation," arranged for one whole floor to be used as a Museum for the exhibition of mechanical devices and for a Cosmorama, for the pleasure, instruction and enjoyment of all who could not visit foreign lands.

The assembling of the necessary objects for this Museum was delayed, as the funds were insufficient, and all the pecuniary resources he had were soon swallowed up by the crying demands for scientific and artistic education, so the reservation even of a small space for the Museum became impossible of attainment. Necessarily the project was laid aside, but never definitely abandoned.

What follows only shows the curious weaving of the web of Fate, where artistic and mechanical tradition appear to have accomplished a foreordained result.

While the Cooper Union was trying to fulfill the colossal educational demands of the public, two little girls with pigtails tightly braided, whose old-fashioned plaid dresses had been cut out and made by their mother on the first Wheeler 8 Wilson sewing machine, were being taken regularly by their father to all places where objects of art were exhibited before their sale at auction. (A letter from Richard Cobden thanks Mrs. Hewitt for two babies' dresses, entirely made by her on the sewing machine, saying the ladies of England could not believe such beautiful work could be done by a lady, entirely on a machine.)

Mr. Hewitt, frail, intellectual, and overworked, who was always giving of his best in the service of the community and of humanity, must have felt it an imperative duty to 
place such interests in his children's minds when the daily life of that day was so utterly different.

New York then offered little in the way of artistic manifestations, though every year there was an appalling mechanical exhibition at the American Institute, at Third Avenue and $63 \mathrm{~d}$ Street, where art was represented by a female figure modelled in butter by a woman sculptress; but there was no incentive or demand for anything better. The prosperous merchants then composing the purchasing public had few dreams beyond the charms of the tormented and over-decorated hardwood trims and atrocities of the degenerate furniture and ceramic forms of the English Gothic revival and the Third Empire. There were, however, some few picture galleries in private houses, most of them filled with black old Italian saints and sinners, which arrived in sailing ships and were sold on the wharves as they were landed as genuine "old masters."

French ancestry had given Abram S. Hewitt innate love of art, and true discrimination. This had been accentuated by his good fortune early in life of his study of the Crystal Palace Exhibition of 1851, which was the first step in the industrial and artistic revival of England, and also in being American Commissioner at the great Paris Exposition of 1855. The Ecole Polytechnique of Paris, and the Royal Society of England had aroused all the keenest intellectual fibres of his soul. He regarded them as the lode stars of the work of the world. A leader in the iron trade, he was in the forefront of every industrial improvement, and as iron and steel are the foundation of the prosperity of nations, he never failed to bring to America every new development, among which were the Sieman's-Martin open hearth and Bessemer processes, and for which both he and Mr. Peter Cooper, the only Americans who ever received it, were awarded the Bessemer Gold Medal, the highest and most coveted distinction which can be obtained by Iron Masters. 
As a young man, Mr. Hewitt walked all over Europe, poverty making it possible for him to select this best and most entrancing of all forms of travel. His wonderful knowledge of the Classics enabled him to enjoy Greece by speaking ancient Greek, and Germany, the Tyrol, Austria, and Italy, where, speaking Latin together, he and an Italian priest made a long walking tour with this as their only means of communication. In this way he was enabled to gratify his burning desire to cultivate himself in all the arts, to study and familiarize himself with the systems of the greatest universities and scientific bodies, so wisely planned in Europe. Such journeys served to crystallize his wish to give the youth of America the best and most legitimate opportunities to study and to achieve.

With his marriage to the daughter of Peter Cooper came the great opportunity of his life, and he threw himself, heart and soul, with singleness of purpose and true devotion, in to the work of another man, to raise the standard of the Cooper Union so high that it should always maintain its leadership in educational matters and stand in the forefront as the starting point and inspiration for thousands of scientific, mechanical, artistic, and industrial careers.

As has already been said, one of the ways he devised for awakening and cultivating the minds of his children, was taking them to exhibitions. It was at great personal self sacrifice and loss of much valuable time, for his occupations were many and his means slender. (As a matter of fact, he had waited seven years before he could afford to marry.) To give his children pleasure and occupation, he placed within their reach in his personal library (which as an honor and special privilege they were permitted the run of), delightful histories and historic fiction to fill their minds with the manners and customs of olden times and countries. There were many years of the "Illustrated London News" with woodcuts of the London and Paris Expositions, which having seen, he could charm into life for them; the "London 
Graphic" showing the work of all the world; Nash's "England," the realistic setting for so many of the great names of history; "Polychromatic Ornament," "The Winter's Tale" and "Joseph and His Brethren," by Owen Jones, were the pleasent entering wedge for arousing interest in design. The reproduction of the "Rosetta Stone," "Wilkinson's Egypt," Rawlinson's "Five Ancient Monarchies" and an "Illustrated Encyclopaedia" brought many ages and lands within range of their vision. Bryant's "Iliad" and "Odyssey," Flaxman's wonderful illustrations, Lemprière's "Classical Dictionary," Hawthorne and Bulfinch, the Waverly Edition of Walter Scott, with its accurate steel engravings of costume, accessories and interiors; twenty-four volumes of "Versailles and Its Galleries," the "Travels of Paul du Chaillu" and Baker in Africa; G. P. R. James, which' they knew by heart, Kingsley, Bulwer Lytton, Disraeli, Jane Austen, Marryat, "The Cloister and the Hearth," "Brakespeare," etc., etc.

Such a list seems primitive as well as curious now, when one has only to choose among the wealth of specialistic publications; but then the field of such literature, particularly anything of an artistic nature, was circumscribed, and suitable memoirs only appeared much later. Nevertheless, these books then formed, and would form now, a suitable background for all later study of art and ornamentation, especially when supplemented by Sismondi, Symonds, Burckhardt and a few others. At any rate such reading placed the children in a position to obtain instruction from each new thing they could observe.

The vagaries of Fate are curious. These young people who were among the pioneers as women sports in riding, driving, hunting and skating, who loved horses and dogs, games, etc., and had imported the first game of lawn tennis from England, were still under sixteen, when with pocket money they might have spent for such amusements, they solemnly purchased at auction, purely for their own pleas- 
ure, half of the Jervis Collection of Textiles, ranging in date from the 12 th to the 16 th century, having an intuition that, as they could not afford all, the earlier portion would possess greater technical and artistic value than the 17 th and 18 th century part. Museums were far from their thoughts, since they had never seen one, but yet this purchase was the initial step, since it now forms a valuable addition to the superb collection presented by Mr. J. Pierpont Morgan to the Cooper Union Museum.

Love of beautiful and exquisite workmanship was an inheritance from two practical and artistic grandfathers who were master workmen and master mechanics and craftsmen. It produced also a natural interest in the arts of decoration, which necessarily remained rather restricted until the grandchildren went to Europe. Before that it was only by putting two and two together and talking with the few art dealers into whose shops they went, that even the rudiments of the knowledge they sought, could be acquired. (The late Henry Duveen started just then in a cellar in John Street, where he made his first sale to Miss Hewitt, who had been taken there by Miss Adelia Cooper, and was fascinated by an enamel watch.)

The bric-à-brac trade was then in its infancy in New York, with only Marly (later Sypher) and a few others. The auction rooms were Leavitt's, and later the American Art Association. Years afterward they were able to add to their education by talking with dealers in London and Paris, and with collectors, such as Messieurs Bonaffé, and EudeI, Messrs. Morrison, Alma Tadema, Sir Frederick Leighton, and visiting the Westminster and Rothschild collections; the South Kensington, Louvre, Versailles and Garde Meuble Museums, and, best of all, Fontainebleau, which is the complete epitome of the history and evolution of the decorative styles in France.

The opening of the Musée des Arts Decoratifs in the Palais de l'Industrie, with its succursal library in the historic 
Place des Vosges, was a perennial source of joy, and brought about an acquaintance and talks with the founders, Messieurs Alfred de Champeaux, Maciet, Berger and others. The girls' interest was intense in hearing first hand accounts of the difficulties in the way of making this Paris Museum of service to the public, for European artist artisans jealously kept tradition and inspiration alive from father to son, and did not feel the need of it; moreover there were models on every side, even in the streets, also learned dilettanti and purchasers, severe in their demands kept up the standards. But such accounts only served to arouse the strong hereditary desire to place similar facilities within the reach of American artisans, and the difficulties appeared as easy to be brushed aside as cobwebs.

In Europe, the pressure of mechanical and industrial development had not then been felt to any great extent, and people educated each other through their innate love of criticism and the habit of discussing every object of art; so when the tormented Directors of the Paris Museum, who were trying to bring its importance and usefulness to the attention of the critics, hoping for favorable notice, had succeeded in collecting a large number of workmen in blouses on a given day, to make an impressive spectacle, their hopes were dashed by the remark of De Goncourt, that their company was "Nombreux, mais peu choisis."

Now here is where the miracles begin and mix with irrevocable Fate.

A substantial anonymous gift permitted the Cooper Union to free the space which it had previously been obliged to rent for income.

Quite ignorant of the immensity of the task they so calmly undertook, the girls, whose pigtails by that time were coiled around their heads, asked for room in which to install a Museum for the Arts of Decoration similar to the one in Paris, for the use of the Cooper Union Art Classes in connection with the courses of instruction. The Trustees, 
recalling the fact that Peter Cooper had designed one floor in his original plan for a Museum, assented. Delightfully, if pathetically innocent and supremely hopeful, it seemed so easy of accomplishment, when willingness, the power of work and of spending their own pocket money, appeared to be all that was required.

With such absurdly limited means, they immediately began the opening of an easier road to knowledge than the one they had so laboriously travelled. Tradition and inherited hardship in acquiring education gave added eagerness to facilitate its free acquirement for others. America was entering a new era, and the Museum so inaugurated, and opened in May, 1895, was the pioneer blazing the trail.

The Directors of the Musée des Arts Decoratifs, singularly broad-minded, and perhaps secretly amused at the youth and inexperience of their collaborators, were generous of thought and time. They personally selected a complete series of decorative casts of the best French periods and styles by the greatest Masters of Ornament, which have since formed the nucleus and backbone, and given the historical sequence to all the later collections. This magnificent and initial gift, the first of many marvels, was presented to start the Museum by Mr. and Mrs. Hewitt.

Then came a wonderful series of happenings. Manufacturers and dealers came forward with. unsolicited help; Chatel and Tassinari of Paris, successors to the great 18 th century firm which had woven the masterpieces of Philippe de la Salle for the bedrooms of Louis XVI and Marie Antoinette at Fontainebleau; Worth, Franck and many other well-known firms gave objects suitable to make small exhibits covering the various branches of the textile and ornamental trades, while the immediate family was laid under heavy contribution. Poor Mrs. Hewitt suffered the most, and as she looked about her devastated home, would often say, "I wonder where that is?" pointing to an empty space; or, 
when visiting the Museum, "Didn't I once have something like that?" thinking she recognized some cherished object.

When everything is a miracle, no one step appears unusual, and each unhoped for and unexpected happening seemed absolutely natural, and served to add impulse to the hopes of the founders, who were trying to create a practical working laboratory in memory of their beloved grandfather.

Each year, the superb and princely gift from Mr. Thomas Snell, of all the necessary painting of walls and woodwork, so worn and old from the constant use of classes, has kept the Museum always fresh and attractive, and every year he sends his receipted bill, together with generous gifts of money to expend.

Soon after it was opened, a prominent and public spirited citizen came to see what this new Museum was. No one had asked him, but his wife and Mrs. Hewitt had been at school together. In response to his request, the girls went to his office in his shop and were startled by his quick remark: "You have undertaken far more than you know, but I am going to help you." He was better than his word throughout the remainder of his life, both with gifts of wonderfully suitable objects, and generous gifts of money brought each year by Santa Claus. Contrary to his usual custom, he made no conditions as to its expenditure. His interest brought luck, for the rule of his life was never to have anything to do with the unlucky. These large sums, given so freely by Mr. George A. Hearn at a time when such objects were still procurable, purchased wonderful things and rapidly placed the Museum in a position as to quality and standard that attracted the help of others. It soon contained sufficient of interest to bring also unpaid intellectual help. For the sake of the knowledge to be acquired in studying sufficiently to be able to write the labels and arrange the objects, such kind friends felt they were repaid a thousandfold for anything they did. 
Had it not been for their initial poverty, perhaps the Directors would never have been in a position to recognize the priceless value of this amateur help. The intellectual aid offered by educated minds, not just to fill unoccupied hours, but from pure delight and interest in the subject, can never be equalled by the paid services of even the high-class assistant. New points of view have brought new arrangements. If the educated mind has met with difficulties, these difficulties have the more easily been swept from the path of the ignorant.

Some Fairy Godmother must have been working overtime waving her wand, for both strangers and acquaintances continually sent gifts, also sums of money, both large and small, to spend, and Good Fortune, ever in the ascendant, has made circumstances as far apart as the poles contribute to the growth and useful power of this baby Museum.

It became known that Signor Piancastelli, Curator of the Borghese Gallery in Rome, had decided to dispose of his collection, consisting of four thousand drawings of the 17 th and 18 th centuries, including the sketch books of several Italian artists who have traveled all over Italy, noting the great ornamental exterior and interior decorations, as well as designs for the ornament of every trade. There were also hundreds of original designs for schemes of decoration for every branch of the ornamental arts. The purchase price of four thousand dollars was contributed, as if by magic, by friends of the Museum. Messrs. Munroe \& Company, of New York and Paris, one of the oldest established banking houses, and a most public-spirited firm, voluntarily conducted all the negotiations, including correspondence, business arrangements, packing, shipping, etc., in order to facilitate bringing this wonderful collection to America. One very curious thing happened, showing that our country was somewhat behind, instead of ahead of the times, as we are so prone to think. Although allowed by law to enter free of duty, since the collection was for a public institution, it 
could not pass the Custom House, for there was no provision in the United States tariff for artists' original drawings; the only ones specified being mechanical drawings. So Mr. Hewitt was obliged to go to Washington to ask the State Department to formulate a special clause covering the entry of original drawings by artists.

Chance brought about a meeting of Mr. Pierpont Morgan and Mr. Hewitt at a men's dinner. The former asked in his usual abrupt, impulsive way, what Mr. Hewitt's daughters were interested in. The reply that they were negotiating the purchase of the unique Badia Collection of Textiles, then for sale in Barcelona, brought out the unexpected request that all the papers relating to it should be sent him that night, as he was sailing for Europe the next day. So, fresh from the typewriter, with hasty penned corrections, he received the rough notes. It may have been their intense quality that interested him, but this is what happened: A few weeks later a cable arrived, which read: "Have purchased the Badia Collection of Barcelona, also the Vivès Collection of Madrid, and the Stanislas Baron Collection of Paris. I do this to give your daughters pleasure." So, in one instant, the Cooper Union Museum jumped to the rank of the South Kensington Museum as to textiles, and even has six pieces that do not exist in the superb Berlin Museum.

One would hardly think that a small family luncheon at the table of the Marquis de Breteuil in Paris would lead to the most wonderful acquisitions that have ever come to this country. Mr. Léon Decloux, an architect decorator, retired from his profession, whose taste and judgment are considered supreme in Paris, was asked to meet the ladies. Mutual interest led to friendship, and with the marked sympathy of the French nation, in regard to matters of art, he was particularly delighted with such a practical attempt to familiarize American artist artisans with the finest forms of French decorative art, and also with the plan of 
facilitating the use of the models and objects instead of holding them to be too precious to be of any real service. He was specifically and delightfully down on the whole profession of Museum Curators, having two in his own family. Much struck with the idea of having the Museum for the use of the community and not for the sole delight of the Curator, he found the attempt of two women to make one very diverting, and, "just to give them pleasure also," invited them to his villa at Sèvres to see his "boiseries" porcelains, ironwork, glass, wonderful furniture and bibelots of all kinds, for during his long life and owing to his profession, his opportunities had been great, especially at a time when interest in this class of beautiful things was very vague, even in Paris. He had no idea of disposing of his collections, since (like Jacques Doucet, who would not let Mr. Morgan see his beautiful home for fear he would offer to purchase, and such a high price be offered that there would be no justification in not selling), but he gladly undertook to expend the small sums the ladies could send, and give all the inestimable advantage of his taste and knowledge. The objects he procured for such moderate amounts soon placed the Museum in the first rank, and later he ceded to it many of his priceless treasures.

Sometimes, with true spirit of adventure, important objects and collections were purchased, even when there was no money to pay, but still Good Fortune, or the Good Fairy, continued their self-appointed duties. A collection of rare old French porcelains and faiences, Menneçy, Chantilly, Sèvres, Rouen, Vincennes, etc., unpaid for, had actually arrived in the Custom House. By the mail that brought the notice, came a letter containing a check, which by accident was the precise amount of the payment. An old New Yorker, at that time unknown to the Directors, wrote charmingly that her interest was great and she wished to help. In thanking Mrs. Trevor, she was asked if she cared to have the money expended for anything of a special nature. Her 
answer, "Oh, I always like old porcelains best," created a tableau.

Another charming New Yorker asked to be shown the Museum. The Directors passed a delightful morning with her. When about to leave she drew from her muff an envelope, saying she wished to make a Memorial to her Mother, but did not wish her name mentioned for some years.

Mrs. William Tilden Blodgett, who had shared her husband's love and knowledge of art (he had formed the earliest and most superb gallery of pictures which contained some chef d'œuvres of 18 th century, English and French art), had been one of the most public-spirited women of her day and had started many successful societies to help women earn their living, which at that time was not easy to accomplish.

Miss Eleanor Blodgett said she knew her Mother would have considered it a great privilege and high honor to have her name connected with the Cooper Union. The cheque was for ten thousand dollars, and the possession of such a large sum of money laid the financial foundation which made the purchase of the Decloux Collection of drawings an absolute certainty.

Since then several other Memorial Funds have been given to use the principal in making purchases, and such untrammelled gifts have placed the Directors in a position to enlarge the scope of the Museum when opportunities occurred to secure art objects of unusual interest, value and beauty.

Among other splendid reasons for the quick advancement of the Museum the thoughtful and generous gift of Mr. Jacob H. Schiff and Mr. Thomas Snell have their place. Each time the ladies went to Europe these gentlemen sent large checks to buy the best that could be found in the way of fine things to enhance the beauty and working qualities of the Museum.

Owing to its restricted space, the Museum must make a general rule not to accept nor exhibit objects later than 
the first quarter of the 19th century; but it gladly accepts one class of objects most essentially modern. Mr. Cooper wished the walls of the corridors and staircases lined with things of interest for those going up and down. As quickly as they can be acquired, leaves from the note and sketch books of artists of the last half of the 19 th century, and of the present day, are being placed there. Distinguished men, namely, Frederick E. Church, Winslow Homer, Robert Blum, many other Americans, also English and Frenchmen, are already represented. The first conception of numerous well-known pictures, perhaps jotted down merely on an envelope, box cover, or chance scrap of paper, are there to inspire and illuminate students and laymen.

By means of such sketches it becomes a privilege to see what these talented men saw all over the world with the argus eyes of artists, so sensitive to impressions of beauty, form, color, light and shade. The value is beyond words, and not one atom of the work of an artist should ever be destroyed since the study of the change of style, manner, technique and character of work and composition from youth to age, often adds valuable instruction, higher inspiration and more lofty conception to the years of student work.

A great power in building up the Museum is the privilege of expending the income of the fund of five thousand dollars given to the Cooper Union by the late Mrs. Robert Stuart for the purchase of art books. Through it, the Reference Library is rich in standard books and richer still in rare books, and the remarkable series of ancient and modern illustrated books are priceless for study.

The fame of the Encyclopxdic Scrap Books, begun over twenty-five years ago, now numbering over one thousand volumes, has recently reached as far as Boston, and only the other day a Head of Department of the Boston Public Library actually came on in person to see what it could be, for what use, and how arranged. He seemed overcome by its practical instructive value, and at the fact that both rare 
and expensive books had been taken apart and remade in a new order to render them more available for study. He was astonished at the large number of illustrated children's books of every age and country, and at the fact of their being constantly consulted for costume and for decorative and color schemes.

The Chart prepared by the learned Directors of the Musée des Arts Decoratifs, Paris, has been of infinite help in arranging these Scrap Books. But, "over there" people begin with more knowledge. Therefore the arrangement of the Chart has necessarily been revised and the books built up from the simplest alphabetical, chronological and geographical arrangement.

Wonders produce wonders. For years, a friend frequently spoke of the work as too extensive for the founders and wished to form a council to give financial assistance. The Directors refused for three years, making the point that the Museum had not as yet proved itself of sufficient value to the public to warrant the investment in it of large sums by other people. Finally, in pure vexation, he said: "Well, I don't care what you think; I will form the Council to give you money to spend." Seeing that Good Luck was not to be denied, the Directors insisted on a Committee of Artists to control their recommendations for expenditure.

With munificence past belief, the Council has facilitated the purchase of hundreds of unique objects, excelling in beauty of design and of exquisite workmanship; the commercial value has increased many hundredfold, and being easy of access to work from, they have been fruitful sources of inspiration and in constant use by artist artisans. The latest and crowning gift of the Council, superb in being the finest and most extensive one known, was the Decloux Collection; four hundred and fifty original drawings by the great "Maitres Ornemanistes," designs created for all the ornament and accessories of palaces and of the hotels and chateaux of the great financiers, to be used by the artist 
artisans who worked out the creations of the masters. These drawings were considered so fine in the day of their making, that the best engravers reproduced them, and so they became known to connoisseurs the world over. No other such collection exists, and the Cooper Union is the proud custodian.

From this description of the making of this Museum, it is evident that it could not avoid being run on lines widely different from those controlling other Museums; and is an amply sufficient reason for the modernism of its use. Restrictions are eliminated, except the few necessary to protect the objects; the salient point is, that the objects are there for use, to be worked from, and, if so desired, to be removed from their positions and placed in any light. They can be photographed or measured (a tape line, not a ruler, must be used), and no squeezes or impressions taken. Naturally constant use will have a tendency to damage, even destroy certain objects (many of course, are indestructible), but irreparable damage could not be accomplished under a hundred years, and if in that time an artistic tradition passed on from father to son, as in Europe has been created, the existence or non-existence of these objects will not seriously matter, and during all that time the Museum will have been fulfilling its destiny.

With another end in view, which is, that people come to this Museum to learn, its objects have been arranged chronologically from earliest to latest, and from left to right, just as a book is written, so that artistic work of many trades and countries at the same period is placed in juxtaposition, to form a practical basis for technical instruction, for ambulant lectures and class work.

The arrangement of the Museum in small sections and with a mass of objects in each is open to some objection, but it does invite much comparison and discussion as to material, workmanship and design, and gives an insight into the artistic work of each epoch all over the world; possibly 
it may in the end bring about the same habit of criticism and discussion that exists in France.

The entrance of this Museum is the most modern of all; it is the main work room and laboratory, in contrast to the great hall of most Museums, delightful with empty spaciousness and with a few superlatively fine objects beautifully and singly displayed. At once on entering, the inspiration of the happy busy atmosphere starts an electric current of sympathy. No explanation seems necessary about the quantity and massing of the objects; there is no feeling of confusion, since each one, or all, are there for immediate use. The artistic values of the masterpieces are accentuated by the others not quite so exquisite, and they stand out as if they were jewels. Such massing of objects becomes legitimate at once. The literary aids of hundreds of Reference and Scrap Books, and of Art Periodicals placed on tables with no hampering restrictions as to their use, puts every resource at the service of the public.

Confusion, if it exists at all, only exists in the untrained mind of the onlooker. For the worker, the source of inspiration is frequently found in the sight of an unexpected object, possibly one of an entirely different trade.

More modern than all else in the use of Museums is the fact, that all work, canvases, objects, etc., may be left out at the owner's risk in the Museum at the close of the day. Every hour and minute that the Museum is open, are working hours and minutes; the worker may be ready to enter at the instant of opening, and not be disturbed until closing time; there are no ten or fifteen minutes' notice to be out, nor the well-known bell, nor the loud words, "on ferme."

The management never loses sight of the fact that the first delightful and wonderful frenzy for work, so well known to artistic temperaments, is easily dashed and cooled by uncongenial influences, petty annoyances and delays, and that those who obtain the greatest benefit from working in 
Museums are frequently ill fed and badly clothed, and the loss of vitality in getting out, carrying to and from the lockers the canvases, easels and materials, frequently militates against the quality and output of the work. The short hours allotted in other Museums are unknown here, and that this special lack of restriction is a valuable asset seems obvious since certain objects, such as an 18 th-century French decorative panel has been already the foundation of the decoration of the walls of three rooms and has enabled one student to earn two hundred dollars, another, five hundred, and a graduate one thousand dollars. A copy of a 17 thcentury Dutch decorative flower piece, founded a business of over five thousand dollars annually, and this same painting is copied nearly every day. Portions of it are to be seen in many present-day decorative schemes, and it is extraordinary how much it constantly adds to other people's incomes. An 18th-century Venetian bedroom set has been copied over thirty times at a cost of one thousand dollars a set. Each copy sells for between twelve and fifteen hundred dollars, which means a gross profit of between thirtysix and forty-five thousand dollars. It means a handsome profit to the various decorators, and a daily wage to artisans varying from two dollars and a half to five dollars.

In reckoning our gains, most of us are pleased with an income of ten per cent. Museums need only be charged with free gifts, since the cost may be set aside to the original donor; so, assuming the profits on this set of furniture to have been at the least, ten thousand dollars, it would make, on what was originally a free gift, a percentage of profit among the trillions. Individual profits of ten per cent. are put to the blush and the "cold tomb of the Museum," so despised by de Goncourt, becomes a living source of artistic supply and a fountain of wealth for the community.

This Museum was formed to facilitate the free acquisition of knowledge in the arts, styles and periods. Its practical relation to the artistic trades is a "First Aid to the 
Ignorant," and many people who visit Museums show such queer elementary forms of ignorance that dealing with them becomes a picture puzzle indeed. Expressions which display a pathetic want of the first principles of knowledge are frequently overheard, such as: "Fifteenth century," "I wonder how old that is?" or "What does 15 th century mean?" Few realize it means the period of years between 1400 and 1500 , nor that it means the object is between five and six hundred years old. Frequently a date is asked, and some salient historical fact should place the information clearly. If the object be Roman, and Julius Caesar mentioned to place date and country, or some object of the French Renaissance by the Massacre of the Huguenots, a breathless pause ensues after the next question, "What is Julius Caesar?" or "the Massacre of the Huguenots?" So even the theory of labelling had to be revised and reduced to the primary elements. First the period, we might choose the "17th century," then in brackets (1600 to 1700 A. D., three to four hundred years old). Possibly Anno Domini should also be explained, but that would take space and complicate the label. Then the country, as France, with the name and dates of the ruler; then the name and dates of the designer and workman, if known; the material the object is made of. Should it be a chair, the component parts are mentioned alphabetically, as Arms, Back, Cover, Legs, Seat. So the intricacies of the design can be simply explained. People are apt to look vaguely and seem unable to observe, no matter how much they wish to learn; if the label is read and a parrot or musical instrument mentioned, interest is awakened, a point of departure found and some recollection of the complete design will be carried away. The end of the label contains the Titles and Authors of the reference books, the numbers of the chapters and pages, and full quotations, so no books need be asked for from the library, a blessed relief to both student and librarian. 
As Peter Cooper, the philanthropist, placed upon the seal of the Cooper Union with the professional pride of a Master Workman, this simple and touching device, "Founded by a Mechanic of New York," so his granddaughters hope the seal of the Museum may some day bear the inscription, "Founded by Hereditary Workers in the Same Tradition."

ELEANOR G. HEWITT. 



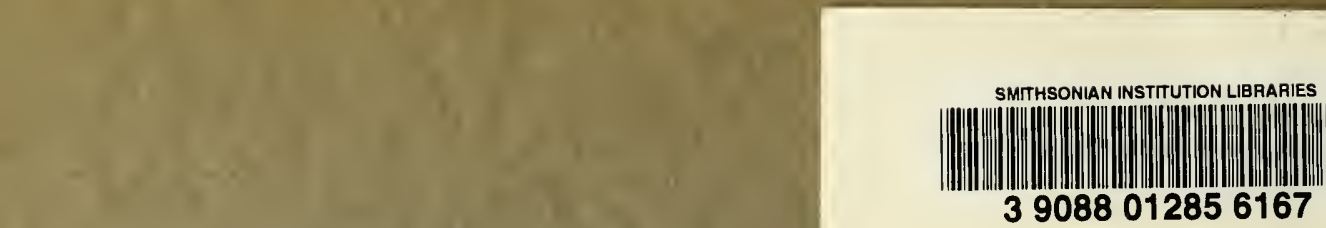

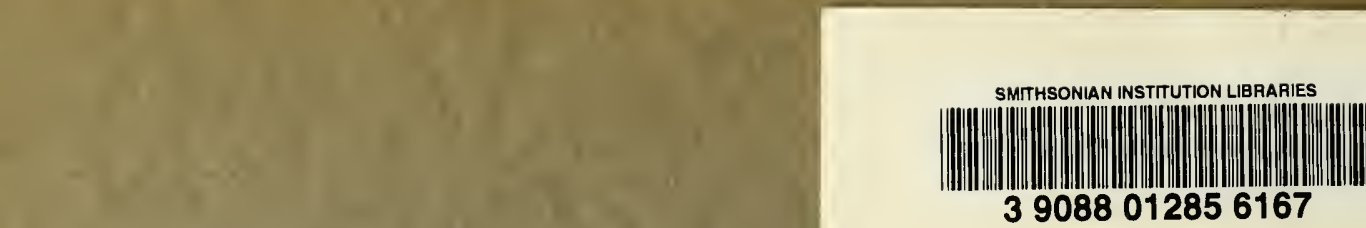

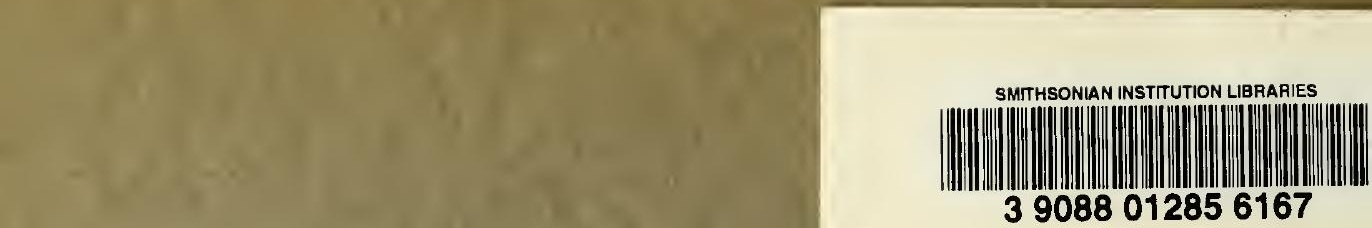

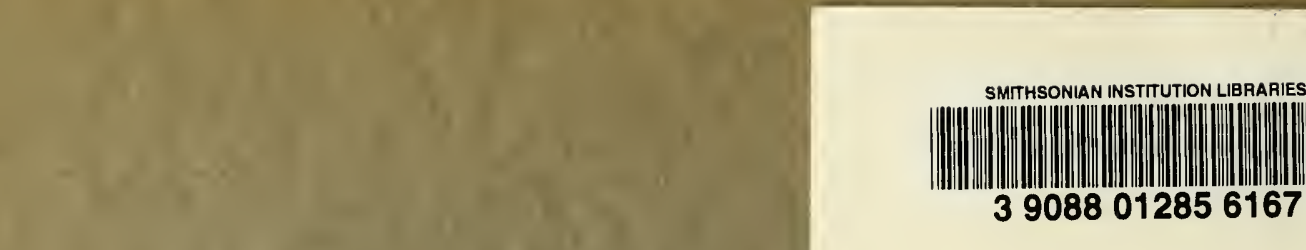
|| $\|$ |WI 更

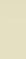

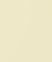

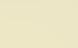

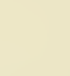

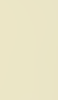
.

.

政

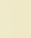
. (1)

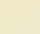

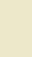

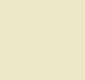

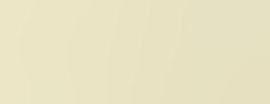

